\title{
Cases of chikungunya virus infection in travellers returning to Spain from Haiti or Dominican Republic, April-June 2014
}

\author{
A Requena-Méndez (ana.requena@cresib.cat) ${ }^{1,2}$, C García $^{2,3}$, E Aldasoro ${ }^{1}$, J A Vicente ${ }^{3}$, M J Martínez ${ }^{4}$, J A Pérez-Molina ${ }^{5}$, A Calvo-

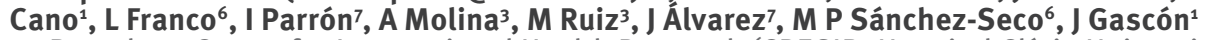 \\ 1. Barcelona Centre for International Health Research (CRESIB, Hospital Clínic-Universitat de Barcelona), Spain \\ 2. These authors contributed equally to this work \\ 3. Internal Medicine Department, Hospital Virgen de la Luz, Cuenca, Spain \\ 4. Microbiology Laboratory, Barcelona Centre for International Health Research \\ 5. Tropical Medicine \& Clinical Parasitology. Infectious Diseases Department, Hospital Ramón y Cajal, IRYCIS, Madrid, Spain \\ 6. National Microbiologic Center. Virology and imported arbovirus department, ISCIII, Madrid, Spain \\ 7. Unitat de Vigilància Epidemiològica Barcelonès Nord Maresme. Agència de Salut Pública de Catalunya. Barcelona, Spain
}

Citation style for this article:

Requena-Méndez A, García C, Aldasoro E, Vicente JA, Martínez MJ, Pérez-Molina JA, Calvo-Cano A, Franco L, Parrón I, Molina A, Ruiz M, Álvarez J, SánchezSeco MP, Gascón J. Cases of chikungunya virus infection in travellers returning to Spain from Haiti or Dominican Republic, April-June 2014 . Euro Surveill. 2014;19(28):pii=20853. Available online: $\mathrm{http}: / /$ www.eurosurveillance.org/ViewArticle.aspx?Articleld=20853

Article submitted on 08 July 2014 / published on 17 July 2014

Ten cases of chikungunya were diagnosed in Spanish travellers returning from Haiti $(n=2)$, the Dominican Republic $(n=7)$ or from both countries $(n=1)$ between April and June 2014. These cases remind clinicians to consider chikungunya in European travellers presenting with febrile illness and arthralgia, who are returning from the Caribbean region and Central America, particularly from Haiti and the Dominican Republic. The presence of Aedes albopictus together with viraemic patients could potentially lead to autochthonous transmission of chikungunya virus in southern Europe.

We report 10 cases diagnosed with chikungunya virus (CHIKV) infection in Spain after returning from Haiti or the Dominican Republic. These are the first cases reported in Spain from travellers returning from Latin America and this should alert clinicians to consider CHIKV infection in any traveller with febrile illness or arthralgia returning from Central America and/or the Caribbean, particularly from Haiti and the Dominican Republic.

\section{Case reports}

\section{Case definition}

In this report, a probable case was defined as a person who was residing in or visited epidemic area within 15 days before onset of symptoms, was presenting with fever and arthralgia or arthritis, and had a positive IgM CHIKV antibody test result; a confirmed case was defined as a positive tests for one of the laboratory criteria, irrespective of clinical manifestations: (i) presence of viral RNA, (ii) specific IgM antibodies or (iii) four-fold increase in IgG titres in paired samples.
Clinical and epidemiological data

Between April and June 2014, 10 patients were diagnosed with chikungunya in Spain. Their age ranged from 21 to 57 years (mean age: 45.7 ) and six were male. All patients presented with fever $\left(337.7^{\circ} \mathrm{C}\right)$ and arthralgia. Four patients also had an itchy rash. Clinical and epidemiological features of the cases of chikungunya are presented in the Table.

\section{Travel history}

Nine cases resided in Catalonia and one in Cuenca, Spain. However, all 10 had a history of recent travel to Haiti and/or the Dominican Republic and for all symptoms had started either when abroad or within five days of their return to Spain.

Seven of the 10 cases had travelled to the Dominican Republic, while two had been to Haiti. One case had visited both of these countries. The seven cases whose travel was limited to the Dominican Republic had done short trips there, which lasted less than a month. These cases included two persons who were visiting friends and relatives (VFR) in very small village near Santo Domingo and another person VFR who stayed in San Cristobal (south of the Dominican Republic). The remaining four of the seven cases had travelled separately all over the Dominican Republic, one during a short period for work and three as tourists. The two cases who had only visited Haiti had been there as part of their job, as they worked for the same company. During their stay, they lived together in the town of Jacmel for eight months before returning to Spain. The case who had been both to Haiti and the Dominican Republic was a tourist who had travelled there for a total period of four months. 
Clinical and epidemiological characteristics of cases of chikungunya in travellers returning from Haiti and/or the Dominican Republic, Spain, April-June 2014

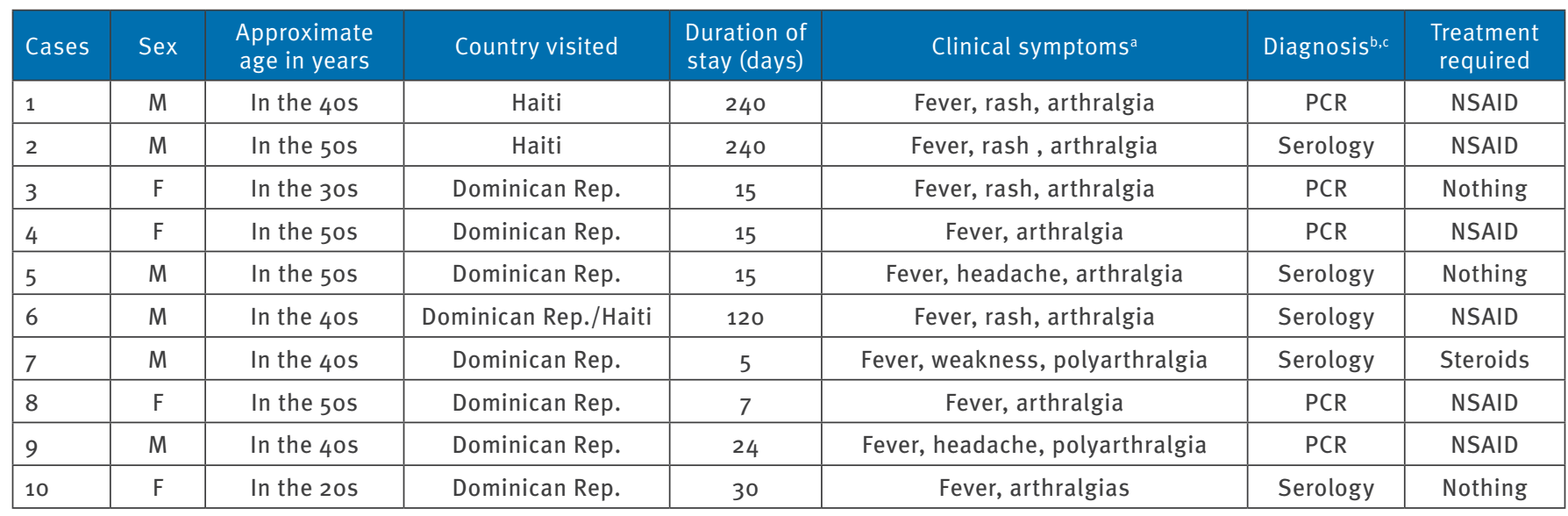

Dominican Rep.: Dominican Republic; F: female; M: male; NSAID: Non-steroidal antinflammatory drug; PCR: polymerase chain reaction. For all 10 cases, symptoms started either when abroad or within five days of their return to Spain.

a Fever was defined as a temperature $>37.7^{\circ} \mathrm{C}$.

b Diagnosis by PCR was done by a real-time reverse transcription-PCR (RT-PCR) (Realstar CHIKV kit, Altona diagnostics).

' Diagnosis by serology included detection of both IgM and IgG against CHIKV in the first sample obtained, using a commercial immunofluorescence assay (Euroimmun). These cases were classified as probable cases.

\section{Laboratory confirmation}

For all cases, dengue virus infection was excluded through either polymerase chain reaction (PCR) or serological tests. In five of the 10 cases, chikungunya diagnosis was confirmed by real-time reverse transcription-PCR (RT-PCR) (Realstar CHIKV kit, Altona diagnostics). In the five remaining patients, chikungunya diagnosis was based both on IgM and IgG antibodies against CHIKV, which were detected by immunofluorescence (Euroimmun). PCR was not performed for such patients because the first diagnostic samples were obtained between 10 and 21 days after the onset of symptoms and the probability of viraemia was very low.

\section{Treatment}

Although their condition significantly improved one or two weeks after symptom onset, the majority of cases required anti-inflammatory therapy. Three weeks after the onset of symptoms, only three patients were still taking anti-inflammatory drugs and one of them required steroids therapy during 15 days due to the persistence of polyarthralgia.

\section{Background}

CHIKV is an arbovirus of the genus Alphavirus transmitted by Aedes mosquitoes (mainly Ae. aegypti and Ae. albopictus) [1].

\section{Clinical manifestations of chikungunya}

The disease caused by CHIKV has an incubation time that ranges from one to 12 days, with an average of two to four days [2] and clinical presentation has similarities with dengue fever. Chikungunya is characterised by fever, headache, rash and both acute and persistent arthralgia. Polyarthralgia is common in cases CHIKV infection and is the most disabling symptom [2]. Around $75 \%$ of infections are symptomatic [3] and general complications are rare but include myocarditis, hepatitis, ocular disorders, central nervous system involvement (encephalitis), and haemorrhagic fever [4]. Although the mortality rate associated with CHIKV is low, the arthralgia can persist or can recur for weeks or months [5] and the likelihood of developing persistent arthralgia is highly dependent on age, being more prevalent in those older than 45 years-old [2].

\section{Diagnosis}

The diagnosis should be based on clinical, epidemiological and laboratory criteria [2]. The laboratory confirmation is crucial to distinguish from other disorders with similar clinical manifestations, such as dengue fever, other diseases caused by alphaviruses, or malaria. In the acute phase of illness, detection of viral nucleic acid in serum by RT-PCR is possible [6]. After this period, diagnosis relies on detection of specific antibodies against CHIKV [7-8]. Laboratory confirmation of CHIKV infection is usually achieved by detection of viral genome or demonstration of seroconversion in paired serum samples [9]. 


\section{Geographical distribution of chikungunya} virus

Until 2005, CHIKV infection was endemic in some parts of east Africa and southeast Asia and cases were also reported from the Indian subcontinent $[2,10]$. Following outbreaks of chikungunya in islands of the Indian Ocean and in peninsular India in 2005 [11], the virus also caused localised outbreaks in some countries in Europe, such as Italy (2007) and France (2010) [12-13]. Before 2013, CHIKV infections had not been detected in the Americas but in December of that year, the first confirmed autochthonous case of CHIKV was reported in the Caribbean, in Saint Martin [14]. Since then, almost 800 confirmed cases of CHIKV infection have been reported from Saint Martin [15] and the virus has spread to the whole Caribbean. As of the end of June 2014 , almost 255,000 suspected cases have been reported from the Latin Caribbean and there are almost 180,000 suspected cases in the Dominican Republic and Haiti, with 18 confirmed cases in the Dominican Republic and 14 in Haiti [15-16].

\section{Investigation of the chikungunya virus sequence derived from a case}

A PCR targeting the partial envelope protein (E) 1 gene was done in addition to the real-time RT-PCR for one case (case 9), who had travelled to the Dominican Republic [17]. Following amplification and sequencing of the gene, basic local alignment search tool (BLAST) analysis revealed a 100\% similarity index of the case's sequence with sequences from strains recently identified in the British Virgin Islands (strain 99659; GenBank accession number: KJ451624) and Saint Martin (strain CNR-20235/STMARTIN/2013, retrieved from the European virus archive (http://www. european-virus-archive.com)) [18]. Phylogenetic analysis, using MEGA5 software showed the strain affecting the patient to be of the Asian genotype, and in the

\section{FIGURE}

Phylogenetic analysis of a sequence derived from a case of chikungunya virus infection in a traveller returning from the Dominican Republic to Spain, April 2014

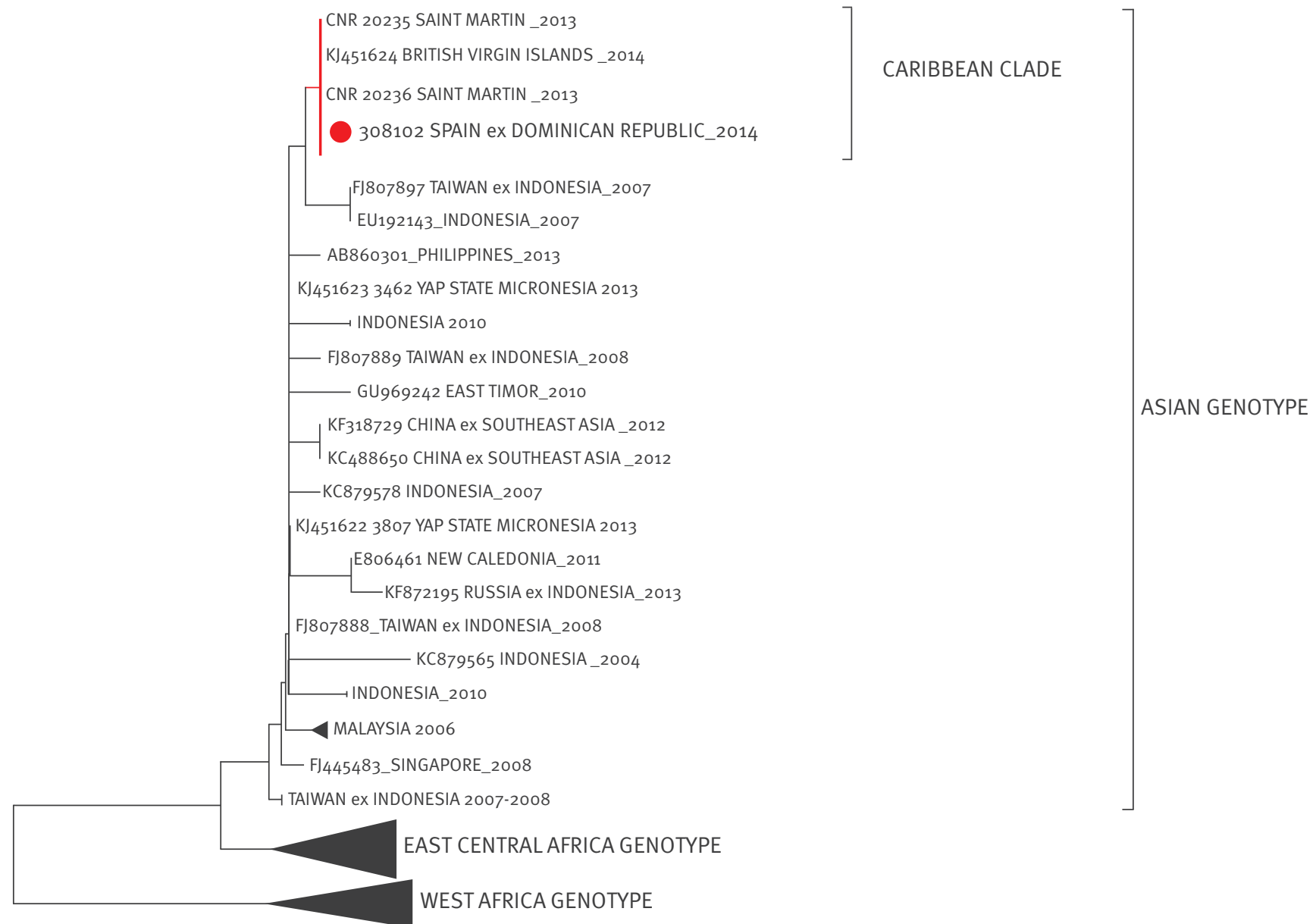


phylogenetic tree, the sequence derived from the case clustered together with other CHIKV sequences from the Caribbean (Figure). The sequence was deposited in GenBank under accession number KM192348.

\section{Discussion}

We report 10 cases of chikungunya in Spain between April and June 2014. Five of these can be considered as laboratory confirmed based on a positive specific real-time RT-PCR. The other five that tested positive for both IgM and IgG CHIKV antibodies can be classified as probable cases.

All cases had a clear epidemiological link to the Dominican Republic and/or Haiti, two countries where they had recently travelled and which were concurrently affected by chikungunya. Symptom onset for all cases occurred either before returning to Spain or within a period compatible with infection abroad, based on the incubation time. Phylogenetic analysis of a viral sequence derived from one of the cases moreover showed $100 \%$ similarity with sequences from strains recently identified in the Caribbean.

After December 2013, when autochthonous transmission of CHIKV was first reported in Saint Martin, the virus spread within a few weeks to most countries of the Caribbean, where an outbreak is currently taking place [18]. A concomitant dengue outbreak in the region complicates differential diagnosis. Chikungunya presents a good example of the interaction between globalisation and emerging infections. During the last 10 years, the virus has spread throughout the Indian Ocean, Asia, and localised outbreaks have also been reported in Europe [2]. Local transmission has been detected in the Americas in recent months. It is predicted that CHIKV will spread in most American areas where Aedes mosquitoes are endemic [14].

Cases of autochthonous transmission have not been reported in Spain but imported cases from countries affected by CHIKV have been documented in the past years $[19,20]$ and a retrospective study reported 14 to 15 cases per year in the period between 2006 and 2007 [21]. Since April 2014 however, due to the situation in the Caribbean region, the numbers of cases have increased and in addition to the cases presented here further more recent cases have occurred (data not shown). According to last data from the World Tourism Organization (data from 2008-2012), Spain is one of the European countries with a largest number of travellers to Haiti and the Dominican Republic [22]. Moreover, the presence of immigrants in Europe from the Caribbean $[23,24]$ may also account for trips to these countries. The number of imported cases of CHIKV into Europe is likely to increase in the following weeks.

Aedes aegypti, one of the main vectors of CHIKV, is present in some areas of Europe, such as Madeira [25]. Ae. albopictus, the other vector, is already established in various countries in Europe, such as Italy, the south of
France and some regions in Spain [26, 27-29]. In Spain, the mosquito is found in most parts of Catalonia, the region where most of our cases (9/10) were residing, and in the Baleares islands as well as some territories of Murcia and Valencia [26]. Although Ae. Albopictus is currently not established in Cuenca, where one of the cases lived, this town is approximately $200 \mathrm{~km}$ away from Valencia.

The presence of a chikungunya vector together with travellers, who are still in the period of viraemia, as for five of our cases, could be a source of local transmission of CHIKV infection. In fact, an outbreak of autochthonous CHIKV infection already occurred in north-eastern Italy in 2007 after an index case arrived from India [30]. This led to an estimate of 254 locallyacquired infections [30]. With vectors established in parts of Europe and the intense circulation of people between this continent and America, there is a threat for new localised outbreaks of CHIKV infection in Europe [18].

At this time, surveillance in the Catalonian region [31] where the vector is established is based on activecase finding. The surveillance is activated when either a confirmed case is detected or when a probable case in Catalonia could be viraemic. Moreover, primary healthcare centres belonging to the local area where the probable or confirmed case is detected are warned and, in parallel, the regional government in Catalonia is trying to activate measures to control the vector in the affected areas.

The set up of a surveillance system that can accurately identify chikungunya cases presents difficulties since the symptoms of the infection are not very specific. However, although confusion between dengue and chikungunya is possible, in most cases the symptoms of chikungunya are specific enough to be recognisable in travellers by clinicians who are aware of the disease.

\section{Conclusions}

CHIKV infection might be suspected in any people returning from the Caribbean with fever, particularly if disabling arthralgias are present. In regions infested with $A e$. albopictus or Ae. aegypti, health authorities should be aware of the risk of local outbreaks and the need to implement control measures for both vectors.

\section{Acknowledgements}

The CRESIB Research group receives funds from AGAUR, (project 2009SGR385) and also from the project RICET (RD12/0018/0010) within the Spanish National plan of R+D+I and co-funded by ISCIII-Subdireccion General de Evaluacion and the Fondo Europeo de Desarrollo Regional (FEDER). CRESIB institution belongs to the TROPNET network. This work has been partially funded by the project Pl10/00069FIS (Fondo de Investigaciones Sanitarias) 
Conflict of interest

None declared.

\section{Authors' contributions}

AR, CG, EA, AC, JAV, AM, MR, IP and JA took clinical care of the patients, since admission to hospital and at outpatient clinic once discharged. MJM, LF and MPSS, performed the laboratory investigations and phylogenetic analysis of the virus, JG and JAPM were the senior supervisor of the article. All authors participated in writing the manuscript.

\section{References}

1. Caglioti C, Lalle E, Castilletti C, Carletti F, Capobianchi MR, Bordi L. Chikungunya virus infection: an overview. New Microbiol. 2013;36(3):211-27.

2. Burt FJ, Rolph MS, Rulli NE, Mahalingam S, Heise MT. Chikungunya: a re-emerging virus. Lancet. 2012;379(9816):662-71. http://dx.doi.org/10.1016/S0140-6736(11)60281-X

3. Van Bortel W, Dorleans F, Rosine J, Blateau A, Rousset D, Matheus S, et al. Chikungunya outbreak in the Caribbean region, December 2013 to March 2014, and the significance for Europe. Euro Surveill. 2014;19(13):pii=20759

4. Farnon EC, Sejvar JJ, Staples JE. Severe disease manifestations associated with acute chikungunya virus infection. Crit Care Med. 2008;36(9):2682-3. http://dx.doi.org/10.1097/CCM.obo13e3181843d94

5. Sissoko D, Malvy D, Ezzedine K, Renault P, Moscetti F, Ledrans M, et al. Post-epidemic Chikungunya disease on Reunion Island. course of rheumatic manifestations and associated factors over a 15-month period. PLoS Negl Trop Dis. 2009;3(3):e389.

6. Panning $M$, Hess $M$, Fischer W, Grywna K, Pfeffer $M$, Drosten C. Performance of the RealStar Chikungunya virus real-time reverse transcription-PCR kit. J Clin Microbiol. 2009;47(9):3014-6. http://dx.doi.org/10.1128/JCM.01024-09

7. Litzba N, Schuffenecker I, Zeller H, Drosten C, Emmerich P, Charrel R, et al. Evaluation of the first commercial chikungunya virus indirect immunofluorescence test. J Virol Methods. 2008;149(1):175-9. http://dx.doi.org/10.1016/j.jviromet.2008.01.004

8. Yap G, Pok K-Y, Lai Y-L, Hapuarachchi H-C, Chow A, Leo Y-S, et al. Evaluation of Chikungunya diagnostic assays: differences in sensitivity of serology assays in two independent outbreaks. PLoS Negl Trop Dis. 2010;4(7):e753.

9. Panning M, Grywna K, van Esbroeck M, Emmerich P, Drosten C. Chikungunya fever in travelers returning to Europe from the Indian Ocean region, 2006. Emerg Infect Dis. 2008;14(3):41622.

http://dx.doi.org/10.3201/eid1403.070906

10. Rao TR. Immunological surveys of arbovirus infections in south-east Asia, with special reference to dengue, chikungunya, and Kyasanur Forest disease. Bull World Health Organ. 1971;4(5): 585-91

11. Manimunda SP, Singh SS, Sugunan AP, Singh O, Roy S, Shriram AN, et al. Chikungunya fever, Andaman and Nicobar Islands, India. Emerg Infect Dis. 2007:13(8):1259-60. http://dx.doi.org/10.3201/eid1308.070193

12. Angelini R, Finarelli AC, Angelini P, Po C, Petropulacos K, Silvi $\mathrm{G}$, et al. Chikungunya in north-eastern Italy: a summing up of the outbreak. Euro Surveill. 2007;12(47):pii=3313

13. Grandadam M, Caro V, Plumet $S$, Thiberge JM, Souarès Y, Failloux A-B, et al. Chikungunya virus, southeastern France. Emerg Infect Dis. 2011;17(5):910-3. http://dx.doi.org/10.3201/eid1705.101873

14. Cassadou S, Boucau S, Petit-Sinturel M, Huc P, Leparc-Goffart I, Ledrans M. Emergence of chikungunya fever on the French side of Saint Martin island, October to December 2013. Euro Surveill. 2014;19(13): pii=20752

15. Pan American Health Organization (PAHO) Epidemiologic alerts. Chikungunya. 6 December 2013. Washington, DC; PAHO; 2013. Available from: http://www.paho.org/hq/index. php?option=com_content $\&$ view $=$ article $\&$ id $=9053 \&$ Itemid $=40$ 695\&lang=en

16. European Centre for Disease Prevention and Control (ECDC). Epidemiological update: autochthonous cases of chikungunya fever in the Caribbean region and South America. 5 June 2014. Stockholm: ECDC; 2013. Available from: http://www.ecdc. europa.eu/en/press/news/_layouts/forms/News_DispForm. aspx? List $=8 \mathrm{db} 7286 \mathrm{c}-\mathrm{fe} 2 \mathrm{~d}-476 \mathrm{c}-9133-18 \mathrm{ff} 4 \mathrm{cb} 1 \mathrm{~b} 568 \mathrm{C} \mathrm{ID}=1018$

17. Collao X, Negredo Al, Cano J, Tenorio A, Ory F de, Benito A, et al. Different lineages of Chikungunya virus in Equatorial Guinea in 2002 and 2006. Am J Trop Med Hyg. 2010;82(3):505-7. http://dx.doi.org/10.4269/ajtmh.2010.09-0435

18. Leparc-Goffart I, Nougairede A, Cassadou S, Prat C, de Lamballerie X. Chikungunya in the Americas. Lancet. 2014;383(9916):514. http://dx.doi.org/10.1016/S0140-6736(14)60185-9

19. Amador Prous C, López-Perezagua MM, Arjona Zaragozí FJ, Martínez-Peinado C. [Chikungunya fever in a Spanish traveller]. Med Clin (Barc). 2007 Jun 16;129(3):118-9. Spanish. 20 MartínFarfán A, Calbo-Torrecillas F, Pérez-de Pedro I. [Imported fever due to Chikungunya virus]. Enferm Infecc Microbiol Clin. 2008;26(6):343-4. Spanish.

20. Martín-Farfán A, Calbo-Torrecillas F, Pérez-de Pedro I. [Imported fever due to Chikungunya virus]. Enferm Infecc Microbiol Clin. 2008;26(6):343-4. Spanish.

21. Sánchez-Seco MP, Negredo AI, Puente S, Pinazo MAJ, Shuffenecker I, Tenorio A, et al. [Microbiological diagnosis of chikungunya virus in Spain (2006-2007): case detection in travellers]. Enferm Infecc Microbiol Clin. 2009;27(8):457-61. http://dx.doi.org/10.1016/j.eimc.2008.07.011

22. World Tourism Organization Network (UNWTO). Yearbook of Tourism Statistics. Data 2008-2012. 2014 Available from: http://statistics.unwto.org/content/ yearbook-tourism-statistics

23. Romero Valiente JM. [La migración dominicana hacia espa-a, factores, evolución y desarrollo]. Rev Eur Migr Int. Université de Poitiers; 2003.;19(1):147-71.Soanish. [Accessed 6 Jul 2014]. Available from: http://remi.revues.org/387

24. [Nuevas migraciones latinoamerianas a Europa: balances y desafíos]. Spanish. Yépes del Castillo I, Herrera G, eds. FlacsoObreal-UCL-UB. [Accessed 10 Feb 2014]. Available from: http:// www.red-redial.net/doc_adj/2417-migraciones.pdf

25. Almeida AP, Gonçalves YM, Novo MT, Sousa CA, Melim $M$, Gracio AJ. Vector monitoring of Aedes aegypti in the Autonomous Region of Madeira, Portugal. Euro Surveill. 2007;12(46):pii=3311 26 European Centre for Disease Prevention and Control (ECDC). VBORNET - Network of medical entomologists and public health experts. Mosquito maps. Stockholm: ECDC; 2014. [Accessed 28 Feb 2014] Available from: http://ecdc.europa.eu/en/healthtopics/vectors/vectormaps/Pages/VBORNET_maps.aspx

26. European Centre for Disease Prevention and Control (ECDC). VBORNET - Network of medical entomologists and public health experts. Mosquito maps. Stockholm: ECDC; 2014 [Accessed 28 Feb 2014] Available from: http://ecdc.europa.eu/ en/healthtopics/vectors/vector-maps/Pages/VBORNET_maps. aspx

27. Bueno Marí R, Jiménez Peydró R. [Health implications of the establishment and spread of Aedes albopictus in Spain]. Rev Esp Salud Publica.2012;86(4):319-30. Spanish.

28. Vega-Rua A, Zouache K, Caro V, Diancourt L, Delaunay P, Grandadam M, et al. High efficiency of temperate Aedes albopictus to transmit chikungunya and dengue viruses in the Southeast of France. PLoS One. 2013;8(3):e59716. http://dx.doi.org/10.1371/journal.pone.0059716

29. Carrieri M, Angelini P, Venturelli C, Maccagnani B, Bellini R. Aedes albopictus (Diptera: Culicidae) population size survey in the 2007 Chikungunya outbreak area in Italy. I. Characterization of breeding sites and evaluation of sampling methodologies. J Med Entomol. 2011;48(6):1214-25. http://dx.doi.org/10.1603/ME10230

30. Rezza G, Nicoletti L, Angelini R, Romi R, Finarelli AC, Panning $M$, et al. Infection with chikungunya virus in Italy: an outbreak in a temperate region. Lancet. 2007;370(9602):1840-6. http://dx.doi.org/10.1016/S0140-6736(07)61779-6

31. Subdirecció General de Vigilància i resposta a Emergències en Salut Pública. [Procediment d'actuació davant casos sospitosos produïts pel virus Chikungunya a Catalunya]. 2014. Spanish. [Accessed 17 Jul 2014]. Available from: http:// www20.gencat.cat/docs/canalsalut/Home\%20Canal\%20Salut/ Ciutadania/La\%20salut $\% 20$ de $\% 20$ la\%20A\%20a\%20la\%20 Z/C/Chikungunya/Procediment_Chikungunya.pdf 